\title{
Klumime: EU's voksende troværdighedsunderskud
}

\author{
Af Ghia Nodia
}

EU har vist sig uden rygrad over for russisk aggression og har derved mistet troværdighed. Hård magt har ganske vist aldrig været Unionens største styrke, men for at den kan genvinde sin bløde magt, er det nødvendigt den først genvinder den hårde.

Topmødet i EU's Østlige Partnerskab i Riga den 21.-22. maj i år kan opsummeres med ét ord: Skuffelse.

Georgien, Moldova og Ukraine trodser store besværligheder - herunder økonomisk pres fra Rusland og trusler om militær konfrontation - i deres søgen efter at styrke båndene til den Europæiske Union. Og alligevel er de europæiske ledere fortsat så fikserede på teknikaliteter, at det nærmer sig en afvisning, jævnfør bare deres vægring mod at give ukrainske og georgiske statsborgere lov til at rejse til EU uden visum. EU's krumspring er efterhånden blevet så frustrerende, at de underminerer opbakningen til europæisk integration.

Georgien er det land, hvor opbakningen til europæisk og euroatlantisk integration traditionelt har været størst, men her viste en nylig meningsmåling, at 31 pct af de adspurgte støttede en tilslutning til præsident Putins yndlingsprojekt, den Eurasiske Økonomiske Union (EEU).
For bare et år siden var det tilsvarende tal 16 pct. Skønt støtten til Georgiens fortsatte bestræbelser på at knytte tættere bånd til EU stadig er meget højere - 68 pct. -var det en forskydning, der bekymrede georgiske eurofile.

Den øgede støtte til EEU-medlemskab kan skyldes øget frustration over EU's lunkne holdning til en yderligere udvidelse af unionen. Den kan også være drevet frem af den stadig mere intensive russiske propaganda - på trods af ind imellem virkelig bizarre påstande. Men diskussioner på de lokale sociale netværk og samtaler med mine medgeorgiere antyder, at den mest tvingende grund til, at Georgien i stigende grad vakler i spørgsmålet om EU-medlemskab, skal findes i Ukraine.

Sagen er, at Ukraine klart valgte Europa frem for Rusland - og blev straffet hårdt. Rusland invaderede og annekterede en del af dets territorium, mens Europa så på. Putin er måske nok farlig og uforudsigelig, men han tøver ikke med at gøre, hvad der skal til for at fremme Ruslands strategiske interesser, som han ser dem. EU's politik derimod har på det seneste været karakteriseret af ubeslutsomhed og svaghed.

Det handler helt sikkert ikke om, at georgierne foretrækker Rusland, Tværtimod betragter et betydeligt flertal Rusland som

Ghia Nodia er formand for the Caucasus Institute for Peace, Democracy, and Development i Tbilisi, Georgien. 
en trussel. Ved at støtte EEU underkaster de sig Ruslands hårde magt, fordi det er bedre at fodre bjørnen end at konfrontere den på egen hånd.

Hård magt har selvfølgelig aldrig været EU's største styrke. EU's bløde magt er tværtimod dét, der har gjort EU i stand til at udøve sin indflydelse over en stor del af den tidligere Sovjetblok. Men i et barskt nabolag er der også behov for en form for beskyttelse mod utilsløret militær aggression. Det gav EU ikke Ukraine; georgiere - og andre - har taget det til efterretning.

EU's fiasko i så henseende skyldes i høj grad den lethed, hvormed den første østudvidelse forløb. Dens ledere blev forledt til at tro, at ethvert europæisk land ville forandre sig selv grundlæggende for at knytte bånd - omend skrøbelige - til Europa. Og de antog naivt, at den blotte drøm om en dag at blive medlem af EU ville sikre landes loyalitet - selv stillet over for Putins trusler om hård magt. Europæerne synes kort sagt at have overbevist sig selv om, at de er hævede over geopolitiske realiteter.

Men sandheden er, at hård magt altid har været centralt for tiltrækningen ved europæisk integration, idet de tidligere sovjetbloklande betragtede EU og NATO som to sider af samme sag. Faktisk var Europas bløde magt baseret på et løfte om frihed, velstand og sikkerhed, men europæerne foretrak at nedtone sikkerhedsdelen, fordi den var udliciteret til NATO og derfor afhængig af USA.

Den forkærlighed er endnu stærkere i dag, hvor USA's orientering mod Asien svækker den transatlantiske akse. Når alt kommer til alt har EU ikke nogen alternativ sikkerhedsmekanisme. Hvis kri- gen i 2008 mellem Rusland og Georgien ikke kastede tilstrækkeligt lys over EU's faldende sikkerhedsakkreditiver, så har den aktuelle krise i Ukraine så sandelig gjort det. De østeuropæiske lande er nu i gang med at genoverveje de faktiske fordele - og omkostninger - ved integration.

EU kan kun genvinde sin bløde magt i dets østlige nabolag, hvis den genvinder sin hårde magt. I teorien kunne den gøre det uden USA; i praksis har den ikke en chance.

Den europæiske ordens unikke værdi er, at den anerkender og beskytter små og sårbare staters ret til selv at vælge deres fremtid. Det er lige præcis dét, som dagens Rusland, der helt mangler blød magt, ser som en trussel. Putin ved udmærket, at der kun er få lande, om nogen, der ville afvise EU og tilslutte sig Rusland, hvis de havde et ægte frit valg. Selv Hviderusland kan ikke tages for givent $i$ et sådant scenario.

Det forstår de europæiske ledere, og derfor har de gentagne gange bekendtgjort, at alle europæiske lande har ret til at vælge deres egen vej. Men sådanne erklæringer betyder kun lidt, hvis EU ikke skrider til handling for at hævde den ret. EU har vist sig at være uden rygrad over for en russisk aggression, som direkte har sigtet på at afspore europæisk indflydelse - og derved har EU mistet troværdighed.

For at vinde troværdigheden tilbage må EU følge sine ord op med handling. Det bliver ikke let at finde et effektivt svar på Ruslands aggression, men EU’s højt besungne bløde magt afhænger heraf.

(Oversat af Brita V. Andersen)

Copyright: Project Syndicate, 2015. 
4 | UDENRIGS 1 | 2015

FOTO: Project syndicate, 2015 